\title{
Democratic Norms, Empirical Realities and Approaches to Improving Voter Turnout
}

\author{
Sarah Birch ${ }^{1}$
}

Published online: 21 December 2017

(C) The Author(s) 2017. This article is an open access publication

\begin{abstract}
Though falling turnout in recent decades has been recognised as a problem for democracy, the solutions that have been proposed have mostly been drawn from the realms of the marketplace and society, rather than that of democracy. The inadequate empirical theory that subtends many policy initiatives designed to improve turnout accounts for why these initiatives have largely failed to achieve their stated aims. I argue that electoral participation should be seen through the conceptual lens of collective action, and that this approach suggests mandatory electoral participation as an equitable and effective coordination device. I further argue that compulsory turnout offers a good fit with democratic norms of equality, rights and political obligation.
\end{abstract}

Keywords Turnout $\cdot$ Compulsory voting $\cdot$ Democracy $\cdot$ Political equality

\section{Introduction}

Electoral participation is one of the most studied topics in political science. The literature on the forces driving people to the polls is vast, and in recent years there have been a huge number of studies on the declines in turnout that have been witnessed in many established democracies. A smaller, but still sizeable, literature has been devoted to devising policy proposals to boost turnout. This policy literature draws heavily on empirical theories of electoral participation, but the empirical debates also have relevance for normative approaches to electoral participation. There have been very few previous attempts to bring together debates on policies

Sarah Birch

sarah.birch@kcl.ac.uk

1 Department of Political Economy, King's College London, London, UK 
designed to influence turnout and normative theories of participation. That is the first goal of this paper. The second goal of the paper is to ground the normative theory of electoral participation more firmly in the democratic needs of a polity, so as to provide a counterweight to the traditional focus in this literature on the democratic needs of individual citizens.

I argue that policy makers in democracies who have sought to improve turnout in recent years have largely misunderstood the fundamental drivers of abstention and the empirical evidence on how people conceive of the voting act. Most citizens understand voting not in cost-benefit terms, but in terms of the democratic norms of citizenship and duty. The empirical literature shows that people value democracy and voting and that they believe voting is important; at the same time, many fail to vote. The application of cost-benefit principles to turnout has led to the adoptions of inappropriate solutions that have been relatively ineffective at staunching the decline in turnout and have at the same time exacerbated political inequality.

At an election, voters are not faced with a situation that calls for cost-benefit calculation; rather they are faced with a collective action problem. The electoral collective action problem can be reliably solved if citizens credibly commit (collectively bind themselves) to participate. This is a democratic solution to the electoral collective action problem, as democracy is a public good grounded in the norm of equality; thus the benefits of participation should be equally available to all, and the burden of supplying democracy should be borne equitably. To do this, citizens require an institution that would enable coordination. Mandatory electoral participation (with opt-outs) is an institution that satisfies these criteria. It is a fair institution in terms of both inputs and outputs: it institutionalises equitable democratic burden-sharing, it results in outcomes with low levels of political inequality, and it has also been found to lower socio-economic inequality.

In addition to providing a more intellectually coherent and effective approach to addressing declining electoral participation, mandating turnout can also be defended from a normative perspective in that it serves the goals of supporting political equality, protecting rights and institutionalising democratic political obligation. The analysis put forward here thus draws together the empirical and normative strands in the debate about electoral participation in an effort to provide a more solid basis for policy development.

\section{What is Voting at an Election and How Should Electoral Institutions be Assessed?}

An election is a collective act by which the citizens of a polity select their leaders. When a person votes, he or she is participating in that collective act through his or her individual vote. The fact that each vote is (in theory) counted equally and contributes equally to the outcome is the principal way in which people can be said to have equal political rights in a democracy. There are of course other political rights that ought to be equal for a state to be considered a democracy-freedom of expression, freedom of association, etc. - but a state that grants the free and equal 
exercise of these rights and does not grant equal electoral rights is not considered a democracy.

We can consider the act of voting from the point of view of how empirically people understand that act, from the point of view of how people ought to approach their contribution to the electoral process or from the point of view of the role of electoral institutions in a democracy. The first two approaches have yielded understandings of voting as expression of personal interest, judgements about the collective interest or expressions of affect (e.g. Brennan and Lomasky 1993; Downs 1957; Goodin and Roberts 1975; Riker 1982; Weale 2007). Given that elections are held to serve the collective democratic interest, I shall approach the voting act from the point of view of the role of voting in a democracy and what democracy requires of elections.

Democracy, understood in its most basic form as a system of 'popular rule', is a system in which the people are, via the institution of the election, variously construed as serving functions that range, in Riker's formulation, from mandating a collective will with respect to particular policy proposals to exercising their right to remove unsatisfactory leaders (Riker 1982). I shall remain agnostic as to the merits of the various understandings of democracy; I note only that virtually all formulations of democracy posit 'the people' as a collective agent that is constituted in its collective democratic role by the electoral process. When they wake up on election day, the several million voters of a state are private individuals going about their private lives, but in the act of voting they momentarily participate in collective agency and make a collective choice that is then binding on them all collectively. ${ }^{1}$ Leaving the polling station, voters each go their separate ways and make decisive individual choices in the marketplace, but one of the most salient features of electoral choice is the fact that it is not decisive for the individual voter. Given the infinitesimal probability of a single vote altering the electoral outcome, the individual cannot be said to gain anything of substantive value from voting, aside from the satisfaction of having carried out the electoral act itself.

In this sense the benefit of voting is mainly to democracy (or to the polity) not to the individual. It follows that voting should be assessed from a normative point of view largely on the basis of the extent to which it benefits the polity, not the individual. A democratic electoral system that violated democratic rights would be problematic (as would be the case for any institution in a democracy), but above and beyond that imperative, impact on individuals should not be an important criterion for choosing between different electoral institutions, as electoral institutions are not for individuals, they are for 'the people'. If a given electoral arrangement improves turnout, this will not be of material benefit to any individual, but it will be of benefit to 'the people'. Another way of putting this is that in the electoral arena, citizens serve the collective good.

\footnotetext{
1 This is in some senses a simplification, as in parliamentary elections the outcome of an election is a parliament made up of a number of representatives, so the choice is a plural choice, but the point remains that it is not an individual choice that results in an outcome specific to the individual voter.
} 


\section{The Empirical Theory of Electoral Participation: Policy Approaches to Improving Voter Turnout}

In recent years there have been a number of experiments with different approaches to improving voter turnout. The most common type of experiment has involved altering the perceived cost-benefit calculus made by the voter when contemplating the voting act. I shall argue that the cost-benefit approach misconstrues the voting act empirically, as most voters do not see voting in this way. For this reason, 'economic' approaches to improving turnout have been largely unsuccessful and they have in some cases even resulted in increases in turnout differentials among groups in society.

\section{'Economic' Approaches to Voting}

Voting has long been a problematic behaviour for economic theories of voting, though that has not prevented policy makers from taking a broadly economic approach to improving turnout. The so-called paradox of electoral participation is said by political scientists to be 'the paradox that ate rational choice theory' (Grofman 1993), as rationalist explanations are unable to account for one of the most basic behaviours in democratic life. Anthony Downs was one of the first scholars to introduce to political science the idea of the 'rational' voter whose electoral behaviour is shaped by perceptions of personal advantage derived from cost-benefit calculations (Downs 1957). Yet Downs recognised that this instrumentalist perspective struggles to account for the most widespread behaviour in the electoral arena: the act of voting itself. This he labelled 'the paradox of voting'. Voters may perceive that they would derive more personal benefit from one party being in power than another, but given the miniscule magnitude of their own contribution to the electoral outcome, and given the cost (in terms of time and effort) of attending the polls, it is difficult to see how voting could be deemed 'rational' in any narrow sense of the term. The decision to participate is both logically and temporally anterior to vote choice; the 'irrationality' of participation thus calls into question the entire behavioural edifice that scholars have sought to construct over the past 70 years on Downsian foundations. Not surprisingly, considerable effort has been devoted to overcoming this apparent paradox, and to supplying an explanation for turnout that accords with cost-benefit assumptions.

While it is not my intention to provide a detailed summary of this debate, ${ }^{2}$ a sampling of the various arguments that have been advanced to salvage 'rational' electoral participation will help to situate my subsequent discussion. Riker and Ordeshook (1968) were among the first to offer a solution to the 'paradox of voting' that was both simple and compelling. If the personal 'reward' from voting is labelled $R$, the cost-benefit calculation proposed by Downs can be rendered as the differential benefit the voter receives from the preferred electoral outcome, $B$, multiplied by the probability that the act of voting will bring about that benefit, $P$, minus the cost of voting, $C$ :

\footnotetext{
${ }^{2}$ For an overview of this literature, see Geys 2006.
} 


$$
\mathrm{R}=(\mathrm{B} * \mathrm{P})-\mathrm{C}
$$

Given that the value of $P$ is tiny in all but very restricted electorates, the product of $B$ and $P$ is bound to be small, even for those who see the outcome of the election as having quite significant implications for their welfare. When one then subtracts $C$, the resulting equation is in most real-world situations likely to deliver a negative value on $R$. Riker and Ordeshook solve this problem simply by adding a term $D$ to the right-hand side of this equation to account for the perceived 'duty to vote' that drives many electors to the polls:

$$
\mathrm{R}=(\mathrm{B} * \mathrm{P})-\mathrm{C}+\mathrm{D}
$$

At real-world values of $D$, this additional term is sufficient to tug $R$ into positive figures, thereby explaining why people vote in significant numbers.

Many subsequent scholars of electoral participation have accepted the Downsian framing of the voting act together with the Riker-Ordeshook patch that renders it plausible, discussing turnout in terms of $B, P, C$ and $D$ (e.g. Aldrich 1993; Blais 2000; Ferejohn and Fiorina 1974; Franklin 2004, chap. 2). Yet the addition of $D$ has made some commentators uneasy, as it has been recognised as a fudge. The concept of 'duty' could plausibly upset quite a number of the cost-benefit calculations that subtend accepted notions of instrumental behaviour, including those underlying actions in settings as diverse as markets, coalition bargaining and trade negotiations. Distributed liberally enough, $D$ terms could potentially undermine the very foundations of mainstream political economy. At the same time, other efforts to 'save' turnout for theories of strategic behaviour have not fared much better. The notion that voters vastly overestimate $P$ (the likelihood that their vote will make a difference), has not been well supported by empirical evidence. It has also been difficult to find empirical back-up for the idea that people derive social benefits from voting (pleasing or impressing friends and relatives) that outweigh the costs.

So, if we accept that it is 'irrational' to vote (when rationality is understood in a purely utilitarian sense), how do we account for the millions of people who troop regularly to the polls? Brennan and Lomasky (1993) argue that cost-benefit analysis is an inappropriate frame for the voting act. They see voters as wearing 'two hats', one for the marketplace and another for the ballot box, and they maintain that 'ethical considerations dormant in market behaviour become significant in the polling booth' (Brennan and Lomasky 1993, pp. 2, 16). For these authors, people vote expressively; they vote because they want to feel part of the electoral event, in the same way that one might choose a side to support in a football match, in order better to enjoy the contest through inclusion in the ritual. They therefore substitute $E$, 'expressive' benefit, for Riker and Ordeshook's $D$ (duty). Yet this argument fails adequately to account for the fact that there are regular and well-documented sociodemographic patterns to voting, and it is not obvious that groups most inclined to attend sporting events are drawn to the polls in disproportionate numbers. The expressive theory of voting still fails to account well for why some vote and others do not. 


\section{'Sociological' Accounts: Electoral Participation as the Result of Norms}

Not a few scholars have argued that it makes little sense to consider voting purely in terms of individual incentives without reference to the social setting in which it occurs. Many see voting as falling below the threshold for serious cost-benefit analysis, as calculatory effort itself entails some cost to those who undertake it. There are plenty of things we do in our daily lives without first weighing the likely 'reward' we will derive from those actions against the expected effort or other costs they involve. When we complete a survey or sign a petition, we tend do so irrespective of personal benefit. Those who view the turnout decision in cost-benefit terms are therefore making a category mistake by applying a motivational framework that is inappropriate for actions that cost so little. Civic attitudes have been found in a number of studies to be far more powerful motives for voting (Oliver 1999, 2001; Soss and Jacobs 2009; Verba et al. 1995; Verba 2004). It is undoubtedly for this reason that it has been found relatively easy to 'nudge' some people into voting by reminding them of their civic duty or informing them of the proportion of other people in their neighbourhood who have voted (Gerber et al. 2008, 2010); many can quite easily be persuaded to part with $20 \mathrm{~min}$ of their time and a bit of shoe leather, in the same way that they can be jollied into texting a small amount of money to charity by a television comedy show.

The alternative 'sociological' explanation for voting is thus that citizens turn out because it is a social norm, and they do not wish to deviate from that norm (Gerber et al. 2016). This accounts both for temporal regularities in turnout, and also for characteristic turnout levels among different sectors of the electorate. With turnout levels not far above $50 \%$ in many democratic elections, it cannot be said that the social norm of voting is especially strong in all social groups. It may be that in some communities people vote due to social pressures; we know that socially integrated individuals are more likely to vote than those who are socially isolated (Crewe et al. 1977; Fieldhouse and Cutts 2016; Rosenstone and Hansen 1993; Wolfinger and Rosenstone 1980), and that turnout varies with levels of social capital in the local neighbourhood (Oliver 1999, 2001; Soss and Jacobs 2009). But collective social norms alone are insufficient to explain why more than half the population in most democracies regularly makes it to the polls at the time of general elections.

Survey research suggests that personal rather than collective norms account best for turnout. One of the most significant factors in predicting whether someone will vote is their sense of civic duty and more specifically their belief in the duty to vote (Blais 2000; Clarke et al. 2009; Fieldhouse and Cutts 2016; Lewis-Beck et al. 2008; Whiteley 2011; Knack 1992). It may therefore be democratic norms that most accurately account for electoral participation, which is undoubtedly why Riker and Ordeshook plucked duty off the shelf of potential variables to add to their vote calculus model. Some empirical studies have found that members of the younger generation are more calculating in their approach to voting (Stoker 2006; Whiteley 2011), yet civic duty remains one of the strongest empirical predictors of turnout.

The puzzle of voting therefore remains. Norms can potentially be invoked to account for the turnout behaviour of a portion of the population, and instrumental reasoning for another portion, but on their own, neither rationalist nor sociological 
theories admit of populations so divided in their fundamental motivations for action. Both these approaches are thus unsatisfactory from a conceptual point of view, even if in combination they can be used to account empirically for much electoral participation.

\section{Electoral Participation as a Collective Action Problem}

An alternative to both the rationalist and the sociological perspectives is to view voting as a collective action problem, an approach that has been outlined in several normative discussions, including most notably those of Lisa Hill (Brennan and Hill 2014; Hill 2002a, b; 2006; cf. Elster 2000, p. 94; Knack 1992; Lijphart 1997). This approach synthesises the findings of the empirical literature in a more coherent conceptual framework than that offered either by the economics of cost-benefit calculations or the sociology of voter norms. The notion of the collective action problem is a thoroughly instrumental one, in as much as it acknowledges the welldocumented human propensity to respond to incentives and to weigh costs (Olson 1971). Yet collective action problems are problems experienced relationally, within groups grounded in specific social contexts. Voting fits easily into the mould of the democratic collective action problem. Voters value democracy and they recognise elections as a necessary element of modern democratic systems. They are also aware that elections require voters, so they recognise the collective rationality of voting and the burden that places on them as citizens. The norms of democracy and the importance of voting are thus ingrained in the popular consciousness as the proponents of normative approaches would have it. Yet voters do not necessarily see themselves as being personally necessary to democracy; their practical experience of elections tells them that enough people typically turn out at the polls for the legitimacy of that process not to be at any great risk. They are rational actors, not insomuch as they spend their waking days hunched over cost-benefit calculators, but in that their attention and time is often diverted by activities from which they derive sufficient benefit that voting is not always a priority. So if they vote, they vote 'lightly', in the sense that they feel little compulsion-rational or normativeto do so, and they experience only moderate, if any, guilt if for whatever reason they should fail to make it to the polling station. Given that the polls are such a weak magnet, voting is one of the activities that can be effectively encouraged via selective incentives. The so-called social benefits of voting are one such incentive, as is the psychological benefit of taking part in a collective ritual. As with many collective action problems, mobilisation by elites also draws people to take part in elections. Such incentives are insufficient to drive many electors to the polls, such that the decline in the perceived duty to vote has resulted in a secular decline in aggregate turnout.

In the face of collective action problems such as this, collectivities experience inequality: all derive equal benefit from the good supplied (in this case the institution of democracy), and the burden of supplying that institution in theory falls on all equally, yet some always seem to shirk their duty. There are complex reasons why this might be the case with voting: groups that are known to vote with high probability-e.g. the middle-aged-are more likely to be catered to by policy 
makers, such that members of largely non-voting groups over time come to the accurate realisation that policy makers pay scant attention to their needs; this further discourages them from engaging with the democratic process and reinforces the vicious cycle of disengagement and under-representation (Birch et al. 2013; Griffin and Newman 2005; Hill 2006; Martin 2003).

The collective action failure of voting in modern democracies has a significant impact on the ability of those polities to deliver policies that speak to the needs of the entire citizenry. This is not due to any deficiency in the citizenry itself, but due to the fact that in any collective action setting, some will take part, but many will shirk, and the shirkers will have distinctive socio-demographic profiles.

\section{Approaches to Improving Turnout}

Much of the effort heretofore devoted to improving turnout has focused on reducing the costs of voting, as electoral participation has been viewed in cost-benefit terms. Yet these efforts have been largely ineffective, and where they have been effective, they have mainly served to reinforce existing socio-demographic inequalities in participation. The same is true of efforts to remind citizens of their electoral duty. Were policy-makers to view turnout instead as a collective action problem, this would suggest different remedies. To be overcome effectively, collective action problems often require coordinating devices that spread the burden of providing the good in question across the collectivity. As noted by Mancur Olson, the intellectual source of modern understandings of collective action problems, 'in a large group in which no single individual's contribution makes a perceptible difference to the group as a whole [...], it is certain that a collective good will not be provided unless there is some coercion or some outside inducements that will lead the members of the large group to act in their common interest (Olson 1971, p. 44; italics in the original). Voters are cognisant of the collective benefits of voting, yet they have no effective means of coordinating to ensure equitable burden-sharing in the electoral arena. The result is electoral processes that serve the needs of some groups better than others. This is unfortunate in a democracy, as it restricts the equality we associate with electoral principles to entitlements. If instead the democratic principle is extended to electoral duties, this serves at once to enrich democracy and to overcome the electoral collective action problem.

The logical democratic solution to the electoral collective action problem is thus to provide citizens with institutions that enable them to coordinate to ensure equitable participation. Requiring all eligible electors to take part in elections is such an institution. This is termed 'compulsory voting' in common parlance, though a more technically accurate term is 'compulsory electoral participation', due to the state's inability to make citizens cast a valid ballot. But before reviewing the benefits of compulsory electoral participation, it makes sense to survey the effects of efforts to raise electoral participation by other means.

The economic approach to turnout assumes that participation can be increased by altering the cost-benefit calculation employed by voters in deciding whether to turn out. Given the practical impossibility of manipulating the 'benefit' side of the equation, efforts are typically focused on the 'cost' of voting, which is targeted with 
various 'vote facilitation' devices designed to make it easier for people to vote. These include enabling easier voter registration, making provision for early and absent voting (including postal voting), allowing voting to take place at weekends or over multiple days and siting polling places in supermarkets or other convenient locations. The record on the success of the different vote facilitation devices is mixed, but one common finding is that when they do improve rates of electoral participation, they tend to do so in particular among those groups already more likely to turn out anyway. In this way vote facilitation often actually increases inequalities in electoral participation. Achen and Sinnott note that 'sufficient facilitation will not overcome an absence of mobilization. Making voting easier will not raise turnout among those who do not wish to vote, any more than making broccoli cheaper will induce people to eat it who despise that particular vegetable' (Achen and Sinnott 2011, p. 2). If vote facilitation increases turnout among mobilised groups but does not affect turnout among the non-mobilised groups, the turnout differential between the two groups will increase, resulting in an increase in political inequality.

An example is the experience of the National Voter Registration Act in the US that came into force in 1995. The Act mandated 'agency-based' registration whereby eligible voters were invited to register to vote in the course of accessing other state systems such as applying for drivers licences, and prevented officials from striking serial non-voters off the voter roll, as had previously been common practice in some states (Piven and Cloward 1996). The new so-called 'motor voter' legislation did increase turnout, but disproportionately among groups already more likely to be on the electoral register. According to an analysis by Wolfinger and Hoffman, there were significant disparities in education levels (12 percentage points), income (four percentage points) and ethnicity (ten percentage points) in willingness to take advantage of the new opportunities (Wolfinger and Hoffman 2001 , p. 88). Thus though the legislation increased overall rates of electoral registration, including those among historically under-registered groups, it simultaneously increased disparities in registration rates between groups.

Another example can be drawn from the UK experience. When turnout fell below the $60 \%$ mark at the 2001 UK General Election, there followed a wave of proposals and pilot studies designed to increase turnout, overseen by the newly created Electoral Commission. The majority of the experiments were aimed at making voting easier for electors, following the cost-benefit logic that has dominated most of the empirical research on turnout to date. Proposed and trialled reforms included early voting, weekend voting, Internet voting, voting at cashpoints or via digital television, voting in supermarkets and other public places, and all-postal voting The only proposal found definitely to increase turnout was all-postal voting (Electoral Commission 2003). ${ }^{3}$ Yet there is evidence to suggest that those most likely to take advantage of opportunities to vote early, vote by post or cast absentee ballots are precisely those who are most likely to vote anyway (Norris 2004). Facilitating the

\footnotetext{
3 Postal voting had recently been made available on demand, in one of the incoming Labour government's early experiments with vote facilitation. This had been found to have had a modest positive impact on turnout, but this effect had been insufficient to reverse the secular decline in rates of electoral participation, prompting the search for more radical approaches, including all-postal ballots.
} 
votes of hardcore voters merely widens the turnout gap between socio-economic groups. Application of the cost-benefit approach to voting has thereby served only to magnify electoral inequality. In as much as the problem of turnout is one of unequal participation between groups, vote facilitation is often actually counterproductive, even if it does marginally improve headline voting figures.

Other proposals have been more obviously based on the normative approach to voting. These include citizenship education in schools, voter education and get-outthe-vote campaigns. The formal Citizenship Education educational programme in the UK that has been rolled out in English schools since 2002 has been found to have had only a very moderate impact on political participation, including voting, among beneficiaries of the scheme (Keating et al. 2010; Tonge et al. 2012). Normbased get-out-the-vote campaigns in the US have actually been found to increase turnout inequality by mobilising participation among those groups that are already most likely to vote (Enos et al. 2014).

Thus policy-relevant measures to increase turnout that rely on the cost-benefit and norm-based understandings of turnout both increase rather than decrease the electoral inequality that makes turnout a problem for democracy. My argument is that rather than focusing on making voting easier for people or using normative suasion to drive people to the polls, electoral reformers should concentrate on making voting more equitable by providing a coordination mechanism to enable citizens to overcome the electoral collective action problem. This approach is both more likely to be effective in achieving its aim, and more democratic. Mandatory turnout is such a coordination mechanism (Hill 2006; Brennan and Hill 2014), practised by approximately a quarter of the world's democracies. Partisan interest has historically been one of the driving forces behind the adoption of compulsory voting, but normative concerns have also been prominent (Birch 2009; Malkopoulou 2015). There is also evidence that compulsory voting was installed in some contexts to strengthen democracy and reduce electoral malpractice (Birch 2009). Far from being a relic of the distant past, compulsory electoral participation is an institution that has been adopted since the Second World War by half the states that use it (Birch 2009), the most recent addition to their number being Bulgaria, which switched to mandatory turnout in April 2016. Absent sufficient instrumental or normative motives in many modern societies to draw people to the polls, electoral compulsion is an effective alternative that has many attractive democratic properties, as will be demonstrated below. ${ }^{4}$

Equitable participation need not involve making electoral participation obligatory for all electors all the time. Individuals might, for example, be required to participate in a certain proportion of elections, and sanctions could be imposed on them only if they failed to meet that requirement. Under such a scheme, electors who, for whatever reason, occasionally failed to make it to the polls would not be punished, but serial non-voters would receive penalties for their failure to contribute on a sufficient basis to the democratic process. In other words, the norm of

\footnotetext{
4 This argument has much in common with those of Hasen (1996) and Hill (2006), who view compulsory voting as an institutional surrogate for civic norms. At the same time I do not necessarily view electoral compulsion as a 'second-best' solution, but rather as a more democratic alternative to electoral voluntarism.
} 
participation would be institutionalised. Other alternatives to full-scale electoral compulsion include first-time compulsory turnout, whereby electors are required to participate once on reaching the age of electoral majority, but are free to opt out of turning out after that (Birch and Lodge 2015). This mechanism is designed to provide a short-term boost to youth voting which would partially right the age-based imbalance in turnout, and to increase voting by all age groups in the longer term by socialising people into voting early in their political lives.

In whatever guise it is adopted, mandatory electoral participation would need to be accompanied by a 'none of the above' or 'abstain' option on the ballot paper, as well as 'conscientious electoral objector' status for those with a deep-seated ideological objection to voting (Hill 2002b; Brennan and Hill 2014). Such an approach is aimed at equalising the cost of voting rather than reducing it (though there may also be other good reasons for reducing the cost of voting where that is feasible through technological or other innovations). Under such an institutional setup, citizens would still have the option of not voting should this be their strong preference, but voting would be reset as the default option (cf. Elliott 2017).

Though it might be objected that allowing participants to abstain obviates the aims of electoral compulsion (Lever 2010; Saunders 2016), there is ample evidence from states where taking part in elections is mandatory that the vast majority of citizens do in fact have preferences over electoral options, and that when they attend the polls, very few of them take advantage of 'abstain' alternatives or the functional equivalent of invalid ballots (Birch 2009; Brennan and Hill 2014, pp. 141-142).

\section{The Normative Theory of Electoral Participation}

I have argued that mandatory turnout provides a practical and effective solution to the electoral collective action problem. In this section I shall demonstrate that this institution also has a number of normative properties that enhance democracy. The empirical variation among democracies in what is required of citizens at election time suggests that democracy is compatible with a range of different institutional arrangements. It is nevertheless of interest to consider whether democracy might be improved or impaired by mandatory participation in electoral processes.

But first it is necessary to clear up come misconceptions about citizen competence and voting. As understood by Robert Dahl and those writing in his tradition, electoral participation in a democracy requires 'enlightened understanding' (Dahl 1989, pp. 111-112). Certain theorists and political scientists have recently argued that a substantial portion of the electorate is not sufficiently enlightened to make an informed choice at the polls, and that it is thus better for democracy if such voters stay at home. There are two separate components to this argument: (1) some citizens are not well enough informed to make sound choices, and (2) it is better for democracy if such voters do not exercise their franchise, as is more likely to be the case under voluntary voting laws. The second argument is dependent for its logic on the first, but the converse is not true. One can hold that some voters do not have enlightened understanding but still believe that they should vote. 
Let us take each of these arguments in turn. First, the argument that it is harmful to democracy that some voters do not have enlightened understanding presumes a certain conception of what constitutes enlightened understanding or informed choice, usually that of the political theorist or political scientists. Scholars such as Brennan and Somin have gone further than this and argued that many voters misapprehend the causal processes that lead to policy outcomes and thus misperceive how given policies will affect them (Brennan and Hill 2014; Somin 2016; cf. Achen and Bartels 2016). A common counter-argument is that voters should be free to decide the basis on which they wish to cast their vote, and that there is no particular reason why democracy requires voters to vote in their individual economic interest (Dahl 1989, pp. 180-181). Likewise, if they do opt to vote in their interest, they should be free to select the interest-measuring heuristic that suits them, even if it provides a somewhat crude measure. If Achen and Bartels's 'blind retrospection' heuristic of punishing politicians when times are tough—regardless of the cause-provides citizens with a 'good enough' means of ensuring accountability, then it is unclear on what basis the political theorist can criticise their decision tool. One might wonder at any theorist who sought to arrogate themselves to the position of deciding what are and what are not 'relevant' political considerations in the polling booth; such a move could be seen as more normatively coercive than mandating attendance at the polls.

But even if we accept that some voters may be less enlightened than the philosophers of ideal democracy might like, it is not obvious that 'faulty' voters ought to be discouraged from voting, or that we should rejoice in their electoral apathy. It might still be held that a 'warts-and-all' democracy is preferable to a system of partial democracy where only a portion of the citizenry takes part. And the 'solution' to lack of sufficient enlightenment might be seen to lie in the electoral institutions themselves, which are demonstrably not fit for purpose if their owners are not able to use them adequately. Rather than lock electors out, we could seek to devise institutions that would go some way towards including and educating them. As E. E. Schattschneider claimed: 'the problem is not how 180 million Artistotles can run a democracy, but how we can organize a political community of 180 million ordinary people so that it remains sensitive to their needs' (Schnattscheider 1960, p. 135). Likewise, Dahl formulates his famous notion of 'enlightened understanding' not in terms of voter knowledge and wisdom, but in terms of aspects of the political system that would foster such knowledge and wisdom: 'each citizen ought to have adequate and equal opportunities for discovering and validating (within the time permitted by the need for a decision) the choice on the matter to be decided that would best serve the citizen's interest' (Dahl 1989, p. 112). Even Achen and Bartels, who have been credited recently with contributing evidence to the argument that many citizens are incompetent voters, argue in favour of rather than against higher turnout: 'we suspect that American government would function better if the poor were better organized and more economically secure, if turnout in elections were higher and more equal, and if campaigns were financed with public funds 
rather than with contributions from billionaires, ideologues and special interest groups' (Achen and Bartels 2016, p. 86; emphasis added).

A further point to consider is which sector of the electorate is least competent to take part in deciding issues of public policy. The common assumption is that it the less informed citizens-also serendipitously those least likely to vote under voluntary voting regimes-whose contributions to political decision-making might be most detrimental to democracy (Brennan and Hill 2014; Somin 2016). For example, Brennan maintains that the typical and median citizen who abstains (under voluntary voting) is more ignorant, misinformed, and irrational about politics than the typical and median citizen who votes. [...] then if we force everyone to vote, the electorate as a whole will then become more ignorant, misinformed and irrational about politics' (Brennan and Hill 2014, p. 85). Yet recent work in the study of electoral behaviour has demonstrated that the most politically aware and sophisticated voters are precisely those whose views are the most severely affected by the cognitive biases familiar to social psychologists and most likely to fall victim to the distorting effects of motivated reasoning (Achen and Bartels 2016, pp. 279, 294; Taber and Lodge 2013). Thus if anyone is to be excluded from participation on the grounds of improving the outcome of democratic choice, it is arguably the political sophisticates most eager to vote. In as much as this group's share in the voting electorate would be diluted by mandating electoral participation, those in favour of 'improving' political decisions by discouraging less talented decisionmakers from taking part should, by their own logic, welcome compulsory voting. Somin, for example, identifies the effect of political engagement on cognitive bias as one of the two principal ills affecting modern voters, together with political ignorance (Somin 2016, pp. 94-96). Curiously, the bias of the engaged disappears in Somin's discussion of antidotes to the failings of modern electorates, which focuses almost exclusively on ignorance and eschews electoral compulsion on the grounds that it would magnify that problem (Somin 2016, pp. 221-222; cf. Somin 2015). That the same device would tend to minimise the twin problem of cognitive bias is not commented on, despite the author's earlier analysis of the dangers of biased ideologues.

Thus it does not follow from complaints about incompetent voters that either exclusion or voluntary voting is a logical remedy to the ills of democracy; enlightened inclusion via institutional reform is a far more democratic alternative. There is every reason to believe that mandating electoral participation is just such an institutional reform, due to its impact on campaign strategy and campaign discourse. Indeed, compulsory electoral participation can go a considerable way towards achieving three of Achen and Bartels's four goals noted above; while it cannot remedy the ills of campaign finance, it can help the poor to organise (and thus potentially improve their economic security through collective electoral action) through raising turnout and making it more equal. Under voluntary voting systems, a large proportion of the effort that parties and candidates put into campaigning is devoted to ensuring that their known supporters turn out to vote. Mobilising the base has become an especial challenge in contexts such as the US, where turnout is unusually low (Gerber et al. 2010; Goldstein and Ridout 2002; Schier 2000). When vote mobilisation is no longer necessary, the efforts of candidates and parties are 
perforce refocused on suasion: securing the vote of undecided voters and converting the adherents of other parties. There is evidence to suggest that this fact has considerable implications for the style of campaigning in which candidates and parties engage; vote mobilisation leads to extremism and demagoguery, whereas the task of suasion lends itself to moderation. We know from decades of research on voting that there is a relationship between negative campaign advertising and electoral behaviour: negative ads make people less likely to vote and lead to a more polarised electorate (Ansolabehere and Ingeyar 1995; Schier 2000). Candidates therefore use negative campaigning to demobilise all but their own strong supporters, and when both sides do this, the result is the abstention of moderates. When this is no longer a viable strategy, the result is likely to be greater moderation.

In tracing the history of compulsory voting in Europe, Malkopoulou notes that one of the previously unremarked reasons why states adopted this measure was that it was seen as leading to more moderate outcomes (Malkopoulou 2015). Likewise, empirical research on more recent periods confirms that contrary to the fears of some, there is no systematic link between rules mandating electoral participation and support for far-right parties (Birch 2009, pp. 125-126).

There is thus every reason to believe that if candidates must seek support for those not already committed to them and their party, they will moderate their stance. Moreover, non-partisan groups typically engage in get-out-the-vote campaigns at election time, whereas if vote mobilisation is no longer necessary, such groups can focus their efforts on voter education instead. Both these factors suggest that when attendance at the polls is mandatory, the language of politics will be more moderate and thoughtful, leaving less room for demagogues and firebrands. Electoral campaigns under such circumstances are likely to be more educational and to focus more on issues, which will increase the capacity of voters to achieve enlightened understanding and make informed choices when they vote.

Having countered the argument that democracy is better off without the contribution of the less informed portion of the citizenry, we can move on to the normative argument for compulsory electoral participation, which will be made in three stages: in relation to equality, rights and democratic political obligation. I shall demonstrate that electoral compulsion performs as well as, or better than, electoral voluntarism on each of these criteria.

\section{Equality}

Political equality is achieved if all citizens have equal opportunity to participate in democratic processes and all voices are equally considered via procedures for achieving popular control of public decision-making (cf. Christiano 2008, pp. 75-130; Dahl 1989, pp. 109-115; Hyland 1995, pp. 51-75; Katz 1997, pp. 100-101; Saward 1998, pp. 49-67). Electoral compulsion contributes to both aspects of political equality.

The socio-economic obstacles to effective participation are many (Verba et al. 1995). Voting is the form of political participation least subject to inequality of access, and it is thus the most common form of participation. Nevertheless, there are in virtually all modern democracies marked disparities in rates of electoral activity 
across socio-economic groups; the young and the poor are typically more reluctant to take part in elections than their older and more affluent counterparts (Blais 2000; Franklin 2004; Norris 2011). The reasons for this are complex, but they involve lifestyle, political engagement and perceptions of political efficacy (Dalton 2004; Franklin 2004; Norris 2011). In other words, there are both behavioural and cognitive elements to patterns of non-participation. The collective action problem inherent in voluntary voting schemes does not completely impede participation; rather, groups in society have differential ability to overcome this problem, depending on their levels of political knowledge, social capital and capacity to mobilise (Soss and Jacobs 2009; Verba et al. 1995).

Given that mandating electoral turnout reliably reduces participation disparities between groups, it goes a considerable way towards addressing inequality of access to political decision-making and achieving 'equal liberty' for all (Lacroix 2007). This is achieved in two ways: (1) in altering electoral behaviour, mandatory turnout includes in electoral processes groups that were previously marginalised; (2) this institution also goes some way towards altering the cognitive orientation of voters towards elections. When participation is universal, political elites have strong incentives to cater to the interests of all citizens and to be responsive to the wishes of all sectors of the electorate, so no group has reason to feel that their interests are being ignored by political elites. It may well be for this reason that levels of satisfaction with democracy have been found to be higher in states with compulsory voting (Birch 2009).

In this way, compulsory turnout ensures that all voices will be equally considered and equally valued in political decision-making. The benefits of equal consideration are both intrinsic and consequential. From an intrinsic perspective, full participation leads to full representation, which can be seen as a democratic value in its own right. More inclusive electoral participation also has the epistemic advantage of generating outcomes that better reflect collective preferences. In Hill's words, 'Since voluntary voting leads to low turnout, and therefore incomplete information about the wishes of the electorate, one could argue convincingly that compulsory voting enhances the democratic principle of popular sovereignty' (Hill 2000, p. 32). This supposition is borne out by empirical research on the impact of electoral compulsion on policy outcomes which shows that higher turnout leads to higher social spending and more even income distribution (Bechtel et al. 2016; Hicks and Swank 1992; Mueller and Stratmann 2003), and that states with mandatory electoral participation have lower levels of political inequality and less corruption than states operating under voluntary voting rules (Birch 2009; Chong and Olivera 2005). These findings suggest that participating in elections benefits the citizenry substantively in that it enables it to hold leaders to account and ensure that policies enacted benefit all sectors of the population. They also suggest that the principal transformative impact of mandatory electoral participation is on political elites, rather than on citizens. This is a topic that would benefit from further empirical research, as most existing studies of the effects of compulsory voting focus on how the institution affects electors. 


\section{Rights}

Whatever the substantive benefits of mandating electoral participation, this institution founders in the eyes of many on the grounds that it impinges on fundamental freedoms. Yet considered from the point of view of the function of elections, compulsory turnout does not impinge unduly on civil or political rights and it enables socio-economic rights; it thus results in a net improvement in rights protection. Let us unpack this argument.

We live in a world of coercion. All human institutions, from marriage to penal systems, condition human behaviour in that they require their members to abide by common norms and contribute to the maintenance of those norms. If institutions, by their very nature, make demands on their members, then the relevant question is not whether such demands and constraints are appropriate, but which types of demands and constraints are appropriate in which contexts.

Whether in its Hobbesian or its Weberian variants, the state is coercive. Indeed, the coercive function of the state is that which grounds political obligation, in as much as obedience to political authority requires recognition of the state's right to compel its citizens to act in certain ways (Horton 2010). One way in which a state coerces its citizens is by requiring them to do things that are in the collective good. There are a wide range of things that are compulsory in most democracies-paying taxes, educating one's children, stopping at red lights, driving on a given side of the road and serving on a jury when called to do so. Compulsion is justified on grounds specific to the norms entailed in the institutions in question-fairness, paternalism, ensuring public safety, coordination and civic duty. When considering whether any given practice ought to be mandatory, there is thus no single set of criteria that can be applied. A case for the benefits of compulsion must be made in relation to the context in which the behaviour in question is undertaken. It has been argued above that an election is a collective act and that electoral institutions ought therefore to be evaluated according to whether they serve the collective good, not the individual good. If 'the people' benefit from mandatory electoral participation, then it is an institution beneficial to democracy, provided it does not unduly impinge on individual rights.

In the electoral context, most democracies make electoral registration automatic or mandatory, but only about a quarter of democracies require their citizens to attend the polls. None require their citizens to cast a vote for an electoral contestant, as this is technically incompatible with the secret ballot (as the marks made on the ballot paper by a citizen cannot be monitored by a state and thus cannot be regulated by law in any meaningful way). Thus no state institutionalises 'compulsory voting' per se, as it is not feasible in a democracy to compel any citizen to cast a valid vote. The question at hand is thus whether it is normatively acceptable to compel attendance at the polls, not voting per se.

As noted above, a system of opt-outs would go a long way towards preventing compulsory electoral participation from being unduly or inappropriately coercive. Yet scholars such as Annabelle Lever, Jason Brennan and Ben Saunders still object to electoral compulsion on the grounds that mandating participation is an inappropriate infringement on political rights and that people have a 'right not to 
vote' (Lever 2010; Brennan and Hill 2014, pp. 3-107; Saunders 2016). In order for these arguments to be convincing objections to mandatory electoral participation, two things must be true: the right-not-to-vote argument must be sound, and this right must override the demands of democracy. I claim that neither of these conditions holds.

Lardy (2004; cf. Lijphart 1997; Brennan and Hill 2014, pp. 154-173) points out that the lack of logic in the common claim that the right to vote entails the right not to vote. Certainly no-one would make this claim of other positive rights, such as the right to a fair trial, the right to equal pay for equal work, or the right to the secret ballot. These are inalienable rights, in the sense that even the holder of the rights cannot throw them off. One is not legally allowed to be paid less than the minimum wage or to have an unfair trial. Unlike so-called 'negative' rights that prevent others from infringing on specified activities (free speech, freedom of belief, freedom of association), rights that underpin equality must be actively supported by their bearers. Thus mandating electoral participation is, with provisions for opt-outs, compatible with the protection of political rights. Saunders accepts the broad parameters of Lardy's argument, but nevertheless maintains that the right not to vote can be defended on liberal grounds independent of its connection to the right to vote, as compulsion constitutes interference in personal liberty (Saunders 2016). Yet in as much as our liberties are continually infringed virtually every waking minute that we exist under the law, this understanding of liberty appears to be divorced from the realities of modern lived existence. One might make similar objections to citizens being coerced into stopping at red lights, paying for food in shops or showing our passports when crossing borders. These forms of compulsion are also infringements on liberty.

Yet even were one to grant the right not to attend the polls, one would still need to demonstrate that this right was sufficiently important to override the demands of effective democratic decision-making. If people have a right not to turn out, the value of protecting this right is proportionate to the harm caused by its infringement. In as much as trooping to the polling station every couple of years and placing a ballot (validly completed or not) in a ballot box constitutes a trivial infringement on a person's rights, complying with this requirement does virtually no harm to any citizen. And any citizen who does feel unduly harmed by the requirement to turn out can, under the scheme envisaged, apply for 'conscientious electoral objector' status. There are a large number of ways in which the demands of the modern state infringe on our rights in far more serious ways, such as the requirement to sit on juries, the requirement to pay taxes and the requirement to die for one's country if asked to do so. These obligations are widely accepted, even though they entail far more significant challenges to citizen liberty. Even if it can be argued that there is a right not to attend the polls, it is a right that soon fades into insignificance in the face of the demands of democracy. As Hill says, 'requiring that people vote is not justified merely because of its good consequences because this could justify all manner of unreasonable compulsions. Requiring people to vote is justified because voting is central to the existence and perpetuation of a cherished way of life on which so much else depends. Indeed, representative democracy is substantially constituted by voting' (Brennan and Hill 2014, p. 162). 
A further argument, and one that is virtually never considered in debates about electoral compulsion, is that mandatory electoral participation enhances the protection of socio-economic rights. We have already seen that compulsory turnout is linked empirically to greater socio-economic equality and reductions in corruption. When citizens are furnished with an effective and convenient coordination mechanism enabling them to overcome the electoral collective action problem, they are better able to act to protect their interests, including both their collective interest in preventing abuse of power, and their interests as members of politically salient groups in society.

The protection of socio-economic rights can be seen as contributing to overall rights protection directly as well as indirectly, in as much as social protection fosters the conditions necessary for what Dahl (1989) calls 'enlightened understanding'. As Bart Engelen argues, 'a purely formal equality of opportunity has to be extended to a more substantial equality of participation and influence' (Engelen 2007, p. 25).

By enhancing the protection of socio-economic rights and not impinging unduly on political rights, compulsory turnout thus leads to a net improvement in rights protection.

\section{Democratic Political Obligation}

The final strand of my argument that mandating electoral participation enhances democracy is that voting is a democratic duty. The notion that voting is a political obligation is deeply embedded in liberal thought (Lacroix 2007; Malkopoulou 2015). In Considerations on Representative Government, John Stuart Mill writes that 'His vote is not a thing in which [a person] has an option; it has no more to do with his personal wishes than the verdict of a juryman. It is strictly a matter of duty. $\mathrm{He}$ is bound to give it according to his best and most conscientious opinion of the public good' (Mill 1999). Bryce put it even more pithily in the early twentieth century: 'as individual liberty consists in the exemption from political control, so political liberty consists in participation in legal control' (Bryce 1921, p. 55).

Yet over the course of the twentieth century, the idea of duties as the natural accompaniment of rights gradually drained out of popular democratic discourse. The equation of 'democracy' with 'freedom' and 'freedom' from non-coercion is now so dominant in popular thinking as to go unchallenged much of the time. But understood as freedom of self-determination (Dahl 1989, pp. 89-91) or freedom from non-domination (Pettit 1997), democratic liberty is consistent with electoral compulsion and a republican grounding of the duty to vote (Brennan and Hill 2014, pp. 167-168; Lardy 2004). Under Philip Pettit's 'inclusive republicanism', a positive value is attached to all sectors of the population manifesting their voice, and Pettit notes that 'if there is a minority of electors who find it difficult or unattractive to register and vote, let alone to stand for office, then it may be desirable to introduce a system of compulsory registration and voting' (Pettit 1997, p. 191).

The institutionalisation of democratic obligation is also consistent with Elster's understanding of democracy as collective self-binding (Elster 1988; cf. Saward 1998). Under a democratic constitution, citizens are bound by decisions democratically taken. Given that they are under obligation to obey the decisions of the 
collective, they have an interest in taking part in the decision-making process. Most citizens are vaguely aware of this, which is why allegiance to the democratic institution of voting typically surpasses participation in those institutions under voluntary voting regimes. Drawing on Elster's notion of precommitment (Elster1979, 2000), ${ }^{5}$ Elliott argues that electoral compulsion can be seen as a means by which the members of a polity can precommit to act in desirable ways that they believe they should do but have trouble doing on their own (Elliott 2017; cf. Elster 2000, p. 94).

Democracy is a public good that must be supplied by the citizens of the democratic polity. Though no polity will draw on the input of all citizens equally, the principles of equality and inclusiveness that ground representative democracy demand of citizens at least minimal participation in the core constitutive choices made in a representative system.

\section{Conclusion}

The economic, sociological and political conceptions of electoral participation start at the same place, but they soon diverge. According to all three conceptions of voting, no individual can anticipate having a realistic chance of influencing the outcome of a public election in a modern democracy. The economic logic views this from a cost-benefit point of view and concludes that voters ought to see so little benefit in voting that they stay at home. Those who take a more sociological approach view voters as being motivated by adherence to social norms of civic duty. But from the point of the logic of democracy, electoral participation is instead a collective action problem. Voters recognise the benefits of voting in the aggregate and lament the state of affairs when turnout is poor, but they have no means of coordinating to ensure an 'adequate' level of electoral participation, and individuals have every incentive to free-ride on the participation of others.

The pragmatic solution to this problem is therefore an equitable means of coordination to ensure an 'adequate' level of participation, by means of some form of compulsory electoral participation, with exemptions for those for whom voting is excessively burdensome, or those who have a deep-seated ideological or other objection to voting. This solves the 'problem' of the cost of voting, not in economic terms by reducing that cost to the level where voters will view it as tolerable relative to the supposed 'benefits' derived from taking part, but in democratic terms by distributing that cost equally among the electorate.

Compulsory turnout simultaneously institutionalises democratic norms and provides a democratic solution to the collective action problems confronting instrumental citizens in the electoral arena. This solution is also one that goes a considerable way towards righting the socio-demographic inequalities that make low turnout so problematic for democracy, and it enhances the democratic values of

\footnotetext{
5 Elster's concept of precommitment can be likened to Brennan and Lomasky's notion of voting and selfpaternalism (Brennan and Lomasky 1993, pp. 143-166), though these authors do not themselves view voting as an appropriate object of self-paternalistic binding (Lomasky and Brennan 2000).
} 
equality, rights and political obligation. Politicians from Winston Churchill to Barack Obama have voiced support for electoral compulsion, and this is an institution that is long overdue for serious consideration by modern democrats.

Open Access This article is distributed under the terms of the Creative Commons Attribution 4.0 International License (http://creativecommons.org/licenses/by/4.0/), which permits unrestricted use, distribution, and reproduction in any medium, provided you give appropriate credit to the original author(s) and the source, provide a link to the Creative Commons license, and indicate if changes were made.

\section{References}

Achen, Christopher H., and Larry M. Bartels. 2016. Democracy for realists: Why elections do not produce responsive government. Princeton, NJ: Princeton University Press.

Achen, Christopher H., and Richard Sinnott. 2011. Learning norms and taking sides: Voter turnout in multi-level systems. Oxford: Oxford University Press.

Aldrich, John H. 1993. Rational choice and turnout. American Journal of Political Science 37 (1): 246-278.

Ansolabehere, Steven, and Shanto Ingeyar. 1995. Going negative: How attack ads shrink and polarize the electorate. New York, NY: Free Press.

Bechtel, Michale M., Dominik Hangartner, and Lukas Schmid. 2016. Does compulsory voting increase support for leftist policy? American Journal of Political Science 60 (3): 752-767.

Birch, Sarah. 2009. Full participation: A comparative study of compulsory voting. Manchester: Manchester University Press.

Birch, Sarah, and Guy Lodge. 2015. Voter engagement, electoral inequality and first time compulsory voting. Political Quarterly 86 (3): 385-392.

Birch, Sarah, Glenn Gottfried, and Guy Lodge. 2013. Divided democracy: Political inequality in the UK and why it matters. London: Institute for Public Policy Research.

Blais, André. 2000. To vote to not to vote: The merits and limits of rational choice theory. Pittsburgh, PA: University of Pittsburgh Press.

Brennan, Jason, and Lisa Hill. 2014. Compulsory voting: For and against. Cambridge: Cambridge University Press.

Brennan, Geoffrey, and Loren Lomasky. 1993. Democracy and decision: The pure theory of electoral preference. Cambridge: Cambridge University Press.

Bryce, James. 1921. Modern democracies, vol. 1. New York, NY: Macmillan.

Chong, Alberto, and Olivera, Maurico. 2005. On compulsory voting and income inequality in a crosssection of countries. Inter-American Development Bank Research Department, Working paper no. 533.

Christiano, Thomas. 2008. The constitution of equality: Democratic authority and its limits. Oxford: Oxford University Press.

Clarke, H. D., David Sanders, Marianne C. Stewart, and Paul Whiteley. 2009. Performance politics and the British voter. Cambridge: Cambridge University Press.

Commission, Electoral. 2003. The shape of elections to come: A strategic evaluation of the 2003 electoral pilot schemes. London: Electoral Commission.

Crewe, Ivor, Tony, Fox and Jim, Alt. 1977. Non-voting in British general elections 1966-October 1974. In Participation in polities: British sociology yearbook, ed. Colin Crouch, vol. 3, 38-109. London: Croom Helm.

Dahl, Robert A. 1989. Democracy and its critics. New Haven, CT: Yale University Press.

Dalton, Russell J. 2004. Democratic challenges, democratic choices: The erosion of political support in advanced industrial democracies. Oxford: Oxford University Press.

Downs, Anthony. 1957. An economic theory of democracy. New York, NY: Harper \& Row.

Elliott, Kevin J. 2017. Aid for our purposes: Mandatory voting as precommitment and nudge. Journal of Politics 79 (2): 656-669.

Elster, Jon. 1979. Ulysses and the sirens: Studies in rationality and irrationality. Cambridge: Cambridge University Press. 
Elster, Jon. 1988. Introduction. In Constitutionalism and democracy, ed. Jon Elster, and Rune Stagstad. Cambridge: Cambridge University Press.

Elster, Jon. 2000. Ulysses unbound: Studies in rationality, precommitment and constraints. Cambridge: Cambridge University Press.

Engelen, Bart. 2007. Why compulsory voting can enhance democracy. Acta Politica 43: 23-39.

Enos, Ryan D., Anthony Fowler, and Lynn Vavrek. 2014. Increasing inequality: The effect of GOTV mobilization on the composition of the electorate. Journal of Politics 76 (1): 273-288.

Ferejohn, John A., and Maurice P. Fiorina. 1974. The paradox of not voting: A decision theoretic analysis. American Political Science Review 68: 525-536.

Fieldhouse, Edward, and David Cutts. 2016. Shared partisanship, household norms and turnout: Testing a relational theory of electoral participation. British Journal of Political Science. https://doi.org/10. 1017/S0007123416000089.

Franklin, Mark N. 2004. Voter turnout and the dynamics of electoral competition in established democracies since 1945. Cambridge: Cambridge University Press.

Gerber, Alan S., Donald P. Green, and Christopher W. Larimer. 2008. Social pressure and voter turnout: Evidence from a large-scale field experiment. American Political Science Review 102: 33-48.

Gerber, Alan S., Donald P. Green, and Christopher W. Larimer. 2010. An experiment testing the relative effectiveness of encouraging voter participation by inducing feelings of pride or shame. Political Behavior 32: 409-422.

Gerber, Alan S., Gregory A. Huber, David Doherty, and Conor M. Dowling. 2016. Why people vote: Estimating the social returns to voting. British Journal of Political Science 46: 241-264.

Geys, Benny. 2006. 'Rational' theories of voter turnout: a review. Political Studies Review 4: 16-35.

Goldstein, Kenneth M., and Travis N. Ridout. 2002. The politics of participation: Mobilization and turnout over time. Political Behavior 24 (1): 3-29.

Goodin, R. E., and K. W. S. Roberts. 1975. The ethical voter. American Political Science Review 69 (3): 926-928.

Griffin, J. D., and B. Newman. 2005. Are voters better represented? Journal of Politics 67 (4): 1206-1227.

Grofman, Bernard. 1993. Is turnout the paradox that ate rational choice theory? In Information, participation, and choice: An economic theory of democracy in perspective, ed. Bernard Brofman, 93-103. Ann Arbor, MI: University of Michigan Press.

Hasen, Richard. 1996. Voting without law? University of Pennsylvania Law Review 144 (5): 2135-2197.

Hicks, Alexander M., and Duane H. Swank. 1992. Politics, institutions, and welfare spending in industrialized democracies, 1960-1982. American Political Science Review 86 (3): 658-674.

Hill, Lisa. 2000. Compulsory voting, political shyness and welfare outcomes. Journal of Sociology 36 (1): 30-49.

Hill, Lisa. 2002a. Compulsory voting: Residual problems and potential solutions. Australian Journal of Political Science 37 (3): 437-455.

Hill, Lisa. 2002b. On the reasonableness of compelling citizens to 'vote': The Australian case. Political Studies 50 (1): 80-101.

Hill, Lisa. 2006. Low voter turnout in the United States: Is compulsory voting a viable solution? Journal of Theoretical Politics 18 (2): 207-232.

Horton, John. 2010. Political obligation, 2nd edn. Basingstoke: Palgrave-Macmillan.

Hyland, James L. 1995. Democratic theory: The philosophical foundations. Manchester: Manchester University Press.

Katz, Richard S. 1997. Democracy and elections. Oxford: Oxford University Press.

Keating A, Kerr D., Thomas B., Mundy E., and Joana Lopes J. 2010. Citizenship education in England 2001-2010: Young people's practices and prospects for the future: the eighth and final report from the citizenship education longitudinal study (CELS), DFE-RR059, London: Department for Education.

Knack, Stephen. 1992. Civic norms, social sanctions, and voter turnout. Rationality and Society 4: $133-156$.

Lacroix, Justine. 2007. A liberal defence of compulsory voting. Politics 27 (3): 190-195.

Lardy, Heather. 2004. Is there a right not to vote? Oxford Journal of Legal Studies 24 (2): 303-321.

Lever, Annabelle. 2010. Compulsory voting: A critical perspective. British Journal of Political Science 40 (4): 897-915.

Lewis-Beck, Michael S., William G. Jacoby, Helmut Norpoth, and Herbert F. Weisberg. 2008. The American voter revisited. Ann Arbor, MI: University of Michigan Press. 
Lijphart, Arend. 1997. Unequal participation: Democracy's unresolved dilemma. American Political Science Review 91 (1): 1-14.

Lomasky, Loren E., and Geoffrey Brennan. 2000. Is there a duty to vote? Social Philosophy and Policy 17 (1): 62-86.

Malkopoulou, Anthoula. 2015. The history of compulsory voting in Europe: Democracy's duty? London: Routledge.

Martin, P. 2003. Voting's rewards: Voter turnout, attentive publics, and congressional allocation of federal money. American Journal of Political Science 47 (1): 110-127.

Mill, John Stuart. 1999. Utilitarianism: On liberty; considerations on representative government. London: Everyman.

Mueller, Dennis C., and Thomas Stratmann. 2003. The economic effects of democratic participation. Journal of Public Economics 87: 2129-2155.

Norris, Pippa. 2004. Will new technology boost turnout? In Electronic voting and democracy: $A$ comparative analysis, ed. Norbert Kersting, and Harald Baldersheim, 193-225. London: Palgrave.

Norris, P. 2011. Democratic deficit: Critical citizens revisited. Cambridge: Cambridge University Press.

Oliver, J. Eric. 1999. The effects of metropolitan economic segregation on local civic participation. American Journal of Political Science 43 (1): 186-212.

Oliver, J. Eric. 2001. Democracy in suburbia. Princeton, NJ: Princeton University Press.

Olson, Mancur. 1971. The logic of collective action: Public goods and the theory of groups, 2nd edn. Cambridge: Harvard University Press.

Pettit, Philip. 1997. Republicanism: A theory of freedom of government. Oxford: Oxford University Press.

Piven, Frances Fox, and Richard A. Cloward. 1996. Northern Bourbons: A preliminary report on the National Voter Registration Act. PS: Political Science and Politics 29 (1): 39-42.

Riker, William. 1982. Liberalism against populism. San Francisco, CA: W. H. Freeman.

Riker, William H., and Peter C. Ordeshook. 1968. A theory of the calculus of voting. American Political Science Review 62: 25-43.

Rosenstone, Steven, and John M. Hansen. 1993. Mobilization, participation and democracy in America. New York, NY: Macmillan.

Saunders, Ben. 2016. A further defence of the right not to vote. Paper presented at the conference on The Ethics of Political Participation, Loughborough, 21 June.

Saward, Michael. 1998. The terms of democracy. Oxford: Polity.

Schier, Steven E. 2000. By invitation only: The rise of exclusive politics in the United States. Pittsburgh, PA: University of Pittsburgh Press.

Schnattscheider, E. E. 1960. The semisovereign people: A realist's view of democracy in America. Boston, MA: Wadsworth.

Somin, Ilya. 2015. President Obama endorses mandatory voting. The Volokh conspiracy, Washington Post 19 March, https://www.washingtonpost.com/news/volokh-conspiracy/wp/2015/03/19/ president-obama-endorses-mandatory-voting/?utm_term=.02e3d6ec9ae1. Accessed 7 Sep 2017.

Somin, Ilya. 2016. Democracy and political ignorance: Why smaller government is smarter, 2nd edn. Stanford, CA: Stanford University Press.

Soss, Joe, and Lawrence R. Jacobs. 2009. The place of inequality: Non-participation in the American polity. Political Science Quarterly 124 (1): 95-125.

Stoker, Gerry. 2006. Why politics matters: Making democracy work. Basingstoke: Palgrave-Macmillan.

Taber, Charles S., and Milton Lodge. 2013. The rationalizing voter. Cambridge: Cambridge University Press.

Tonge, J., A. Mycock, and B. Jeffery. 2012. Does citizenship education make young people betterengaged citizens? Political Studies 60: 578-602.

Verba, Sidney. 2004. Political equality: What do we know about it? In Kathryn Neckerman, ed. Social Inequality, 635-666. New York, NY: Russell Sage Foundation.

Verba, Sidney, Kay Lehman Schlozman, and Henry E. Brady. 1995. Voice and equality: Civic voluntarism in American politics. Harvard, MA: Harvard University Press.

Weale, Albert. 2007. Democracy, 2nd edn. Basingstoke: Palgrave-Macmillan.

Whiteley, Paul F. 2011. The decline (and revival) of the civic culture and participation in Britain. Basingstoke: Palgrave-Macmillan.

Wolfinger, Raymond E., and Hoffman Jonathan. 2001. Registering and voting with motor voter. PS: Political Science and Politics 34 (1): 85-92.

Wolfinger, Raymond E., and Steven J. Rosenstone. 1980. Who votes?. New Haven, CT: Yale University Press. 